\title{
Women's Health, Population Health and Value-Based Care
}

\author{
Mary Ann Wilbur* \\ Department of Gynecology and Obstetrics, Johns Hopkins School of Medicine, USA
}

Submission: April 19, 2018; Published: May 14, 2018

*Corresponding author: MaryAnn Wilbur, Kelly Gynecologic Oncology Service, Department of Gynecology and Obstetrics, Johns Hopkins School of Medicine Baltimore, USA, Email: mwilbur3@jhmi.edu

\section{Opinion}

The US is known to have some of the best health outcomes in the world-for the acutely ill patient requiring expensive care. When compared to other industrialized nations, however, we cannot compete for longevity, quality of life, maternal mortality, or infant mortality [1]. Worse yet, "the gap is growing [2]. This dichotomy between what is and is not available to patients underscores the disparities in the US healthcare system, and the US in general. There is an upcoming opportunity for US healthcare leaders, however. It is the merge of two major issues in our system.

The first issue is our inability to acknowledge that socioeconomic disparities are the single greatest factor in healthcare disparities. The Robert Wood Johnson Foundation and the Center for Population Health at the University of Wisconsin have consistently documented that approximately $40 \%$ of poor health outcomes in the US can be attributed to social and economic factors [3]. The Healthy People 2020 initiative for the US has emphasized the importance of the social determinants of health [4] and the World Health Organization has published frameworks for understanding and integrating the social determinants of health into policies [5]. However, US healthcare policies have not yet consistently incorporated these resources.

The second major issue is that our current fragmented, inefficient, and expensive system has recently reached a critical point on its trajectory [6]. US healthcare economists insist that we must "bend the curve," referring to the $17 \%$ GDP that is currently being spent on healthcare in the US. In response to this second issue, experts recommend a shift towards value-based care [7]. The argument is that the traditional fee-for-service (FFS) system incentivizes the current trend and would keep us on the current unsustainable trajectory. Value-based care is supposed to focus on outcomes of patient care, no on the healthcare itself. But, what outcomes? And how do we define value? And who gets to write the definition?

The Affordable Care Act (ACA) decreased the number of uninsured patients in the US. However, it also sought to answer some of the important questions listed above and to attempt to "bend the curve." The ACA set several projects into motion. It shifted payment schedules, introduced global billing, funded patient-centered research initiatives, and capped hospital payments for adverse outcomes [8]. We have started to feel the effects of these policy changes here in the US and we have also seen them grow dim with recent administrative changes. There will be an ebb and a flow to the evolution of value-based care. However, it is difficult to imagine that this movement will completely change direction. Value-based care is the future of US healthcare. The goal is to decrease the fragmented inefficiencies that persist, because of our FFS system. Proponents of valuebased care envision a streamlined system, providing quality care for less cost. The result is supposed to be a focus on what matters most to patients. The goal is wellness care, not illness care. What value-based experts rarely say, however, is that what they are describing is population health.

Population health, however, will never be achieved, unless we decide to finally address the bigger issue in US health disparitiesthe strong effect that socioeconomic disparities have on health disparities. Healthcare providers from around the world can testify to the all-important effects that poverty and its ills have on health outcomes. They can tell us how racism, sexism, and class affect every patient they see. In the US, we are reluctant to accept this simple truth. There are, of course, pioneers across the country breaking the mold and practicing truly multi-disciplinary care that assesses and addresses the social determinants of health. However, this is not the norm in the US. If we do not systematically address these social determinants of health, we will never meet our mark for value-based care. Instead, what we will do is focus on the wrong outcomes, institute ill-informed policies, provide substandard care, and waste yet more money.

Sadly, this will spell continued disparate outcomes for our young mothers and their infants, as well as our patients with gynecologic conditions, especially gynecologic malignancies $[9,10]$. Because we are at a crossroads in US healthcare, now is the time to implement change. We need to build socioeconomic 
disparities into the policies when implementing value-based care. Although we are quite proud of what US healthcare can provide for the individual patient with acute care issues, we must be humble and look to our international neighbors when considering this next step in US healthcare. Transparency about class, race, sex, and the other social determinants of health will be absolutely necessary when informing population health and value-based care.

\section{References}

1. Papanicolas I, Woskie LR, Jha AK (2018) Health care spending in the United States and other high-income countries. JAMA 319(10): 10241039.

2. Sawyer B, Gonzales S (2017) How does the quality of the US healthcare system compare to other countries? Kaiser Family Foundation: Quality of Care.

3. (2017) County Health Rankings \& Roadmaps.
4. (2020) HealthyPeople2020: Social Determinants of Health.

5. Michael Marmot (2008) Closing the gap in a generation: Health equity through action on the social determinants of health. World Health Organization (WHO) 372(9650): 1661-1669.

6. Lorenzoni L, Belloni A, Sassi F (2014) Health-care expenditures and health policy in the USA versus other high-spending OECD countries. The Lancet 384(9937): 83-92.

7. Porter ME (2010) What is value in health care? New Engl J Med 363(26): 2477-2481.

8. Obama B (2016) United States health care reform: Progress to date and next steps. JAMA 316(5): 525-532.

9. (2018) ACOG Committee Opinion 317: Racial and Ethnic Disparities in Obstetrics and Gynecology. Obstet Gynecol 126(6): e130-e134.

10. https://www.acog.org/Clinical-Guidance-and-Publications/ Committee-Opinions/Committee-on-Health-Care-for-UnderservedWomen/Racial-and-Ethnic-Disparities-in-Obstetrics-and-Gynecology

\section{Your next submission with Juniper Publishers} will reach you the below assets

- Quality Editorial service

- Swift Peer Review

- Reprints availability

- E-prints Service

- Manuscript Podcast for convenient understanding

- Global attainment for your research

- Manuscript accessibility in different formats

( Pdf, E-pub, Full Text, Audio)

- Unceasing customer service

Track the below URL for one-step submission https://juniperpublishers.com/online-submission.php 